\title{
Effect of heat treatment on solubility, surface hydrophobicity and structure of rice
}

\section{bran albumin and globulin}

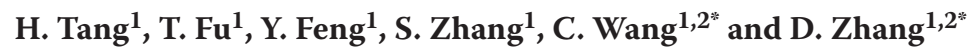 \\ ${ }^{1}$ College of Food, Heilongjiang Bayi Agricultural University, Xinfeng Lu 5, Daqing 163319, China P.R.; ${ }^{2}$ Key Laboratory of \\ Agro-Products Processing and Quality Safety of Heilongjiang province, Daqing 163319, China P.R.; byndwcy@163.com; \\ byndzdj@126.com
}

Received: 11 August 2018 / Accepted: 17 January 2019

(c) 2019 Wageningen Academic Publishers

OPEN ACCESS CC)

\begin{abstract}
The effect of heat treatment on solubility, surface hydrophobicity and structure of rice bran albumin and globulin were characterised. The differential scanning calorimetry (DSC), FT-IR and Raman spectra were used to analyse the effect. The results of DSC analysis showed that albumin denatured after a thermal pre-treatment of $70{ }^{\circ} \mathrm{C}$, while globulin denatured at $90{ }^{\circ} \mathrm{C}$. The solubility of albumin sharply decreased after heat treatment, while the solubility of globulin decreased by up to $100{ }^{\circ} \mathrm{C}$. The results of FT-IR demonstrated that heating globulin generally increased the content of $\alpha$-helix and $\beta$-turn structure, but reduced $\beta$-sheet and random coil structures, while heating albumin produced a pronounced increase in $\alpha$-helix and $\beta$-sheet structures from random coil and $\beta$-turn structures. Heating albumin decreased regions around $33 \mathrm{kDa}$ but increased relative band intensity around 45-53 kDa in SDS-PAGE pattern, while heating globulin up to $90{ }^{\circ} \mathrm{C}$ caused losses in bands around 20 and $50 \mathrm{kDa}$. Raman spectrogram showed that heating albumin induced a slight decrease in intensity of the Trp band. However, the Trp band of heated globulin did not change.
\end{abstract}

Keywords: rice bran, solubility, surface hydrophobicity, structure, heat aggregation

\section{Introduction}

Rice bran is an undervalued by-product of rice milling. Generally, the undefatted rice bran contains $16-22 \%$ fat and $12-16 \%$ crude protein, so it is a good source of protein, fat, and antioxidants. But rice bran is currently underutilised, in spite of its high potential as a raw material for the preparation of functional foods or nutraceuticals (Kennedy and Burlingame, 2003). Rice bran protein (RBP) has been recognised as nutritionally superior to other proteins especially on its reported hypoallergenicity and anti-cancer activity (Helm and Burks, 1996; Shoji et al., 2001). Its protein efficiency ratio of 1.6-1.9 is comparable to the value of 2.5 for casein (Saunders, 1990). Although the nutritional and pharmaceutical potential of RBP has been recognised, at present RBP concentrates and isolates are not commercially available (Chandi, 2008). The main problem limiting the use of these proteins is their high insolubility, due to the aggregation caused by extensive disulphide bonding.
Four types of protein in rice bran (albumins, globulins, glutelins, and prolamins) have been classified by Osborne according to solubility and extractability (Daussant et al., 1983). Albumins, globulins, prolamins, and glutelins are soluble in water, salt solution, alcohol solution, and alkali solution, respectively. Based on recent reports, the fraction of albumin and prolamin in RBP has an average value of 34 and $4 \%$, respectively, while the average value of the fraction of globulin and glutelin is in the range of $15-26$ and $11-27 \%$, respectively (Adebiyi et al., 2007; Hamada, 1997). As major components in RBP, a better understanding of the solubility, aggregation properties and structure of albumin and globulin would help to improve food protein functional properties and adapt the extraction method and purification step.

Commercially, during the rice bran oil extraction process, rice bran goes through a heat stabilisation step to inactivate the lipase enzyme to preserve the quality of oil (Tang et $a l ., 2003)$. It is now known that heat processing denatures 
RBP, which could lead to higher hydrophobicity and affect functional properties, thus making the extraction of RBP more difficult. However, information about molecular size, hydrophobicity, and thermal and functional properties of heated albumin and globulin from rice bran is not available in the published literature. The objectives of this study were to characterise the effect of heat treatment on solubility, surface hydrophobicity and structure of rice bran albumin and globulin.

\section{Materials and methods}

\section{Preparation of rice bran protein}

The bran was defatted using petroleum ether and the resulting defatted bran was suspended in distilled water (1:10). The $\mathrm{pH}$ of the slurry was set at 9.0 using $\mathrm{NaOH}$ solution ( $4 \mathrm{M})$, continuously stirred for $1 \mathrm{~h}$ and centrifuged (12,600 g, $15 \mathrm{~min})$. The supernatant protein solution was adjusted to $\mathrm{pH} 4.5$ using $\mathrm{HCl}$ acid (4 M), stirred for $30 \mathrm{~min}$ and left undisturbed for cold precipitation overnight $\left(4^{\circ} \mathrm{C}\right)$. The supernatant was carefully siphoned off and precipitated protein was washed 3-4 times with distilled water. The protein slurry was neutralised to $\mathrm{pH} 7.0$ and lyophilised (Jouan Nordic, Denmark). The resulting product was termed as RBP.

\section{Separation of proteins from rice bran protein}

Protein extraction was sequentially carried out at $20^{\circ} \mathrm{C}$ by adapting the method of Ju et al. (2001) as described for rice flour protein to that of rice bran (Figure 1). RBP (100 g) was extracted using an Ultra homogeniser (Staufen, Germany) with $400 \mathrm{ml}$ of distilled water for $4 \mathrm{~h}$ and centrifuged at $4,000 \times g$ for $15 \mathrm{~min}$ to give albumin extract. The residue was extracted with $400 \mathrm{ml}$ of $50 \mathrm{~g} / \mathrm{kg} \mathrm{NaCl}$ for $4 \mathrm{~h}$ and centrifuged at $4,000 \times g$ for $15 \mathrm{~min}$ to give globulin extract. The residue was then extracted with $400 \mathrm{ml}$ of $0.02 \mathrm{~mol} / \mathrm{l}$

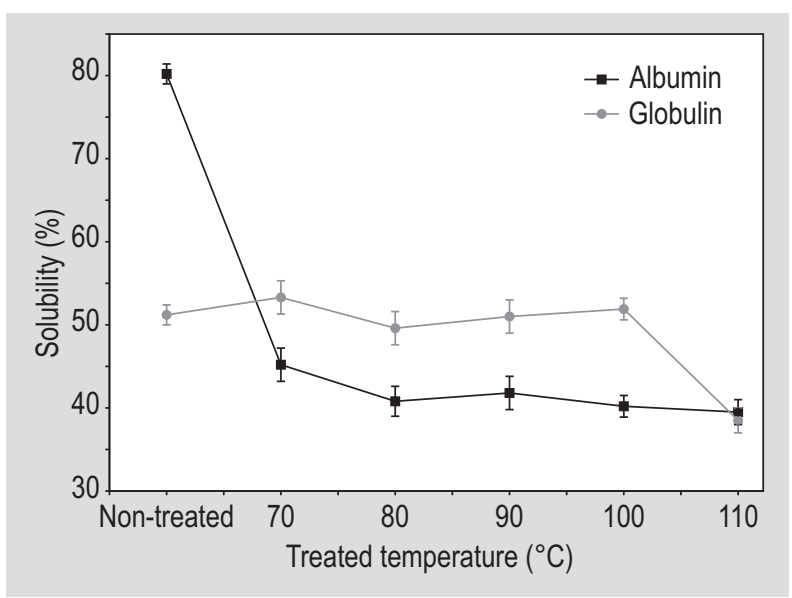

Figure 1. Solubility of globulin and albumin at different temperatures.
$\mathrm{NaOH}$ (pH adjusted to 11.0) for $30 \mathrm{~min}$, and centrifuged to give glutelin extract. The residue was extracted with $300 \mathrm{ml}$ of $70 \%$ ethanol for $4 \mathrm{~h}$ to give prolamin extract.

The sequential extraction step was repeated with $600 \mathrm{ml}$ each of the extraction solvent and the corresponding extract combined. Each extract was centrifuged at $4,000 \times g$ for $15 \mathrm{~min}$ and the supernatant filtered through glass wool. The albumin, globulin, and glutelin fractions were obtained by adjusting the $\mathrm{pH}$ of the filtrate to their isoelectric points of 4.1, 4.3 and 4.8, respectively. The precipitates were allowed to rest for $1 \mathrm{~h}$. The precipitated proteins were centrifuged at $4,000 \times g$ for $15 \mathrm{~min}$, washed twice with distilled water by centrifuging and the $\mathrm{pH}$ neutralised before freeze drying. Prolamin fraction was obtained as precipitate from the ethanol filtrate by adding threefold volume of acetone.

\section{Protein contents}

Protein contents in defatted rice flour, supernatants, and freeze-dried protein products were determined by the Kjeldahl method, and the nitrogen content was multiplied by 5.95 (Juliano, 1985). Protein extraction efficiency (\%) was calculated as a percentage of the summed amount of proteins in the four supernatants to the total protein of defatted rice flour. Recovered efficiency (\%) of each protein was calculated as a percentage of the amount of precipitated, freeze-dried protein from supernatants to the total protein in the supernatants.

\section{Heat treatment}

Albumin and globulin were first dispersed in distilled water, followed by mixing with $\mathrm{pH} 7.6$ phosphate buffer, to give dispersions with desired concentrations $(1 \mathrm{mg} / \mathrm{ml})$. The protein concentrations in the solutions were determined using the Lowry method with bovine serum albumin as the standard protein (Lowry et al., 1951). The aqueous dispersion was placed in a glass tube (sealed) and heated at $60,80,90,100$ and $110{ }^{\circ} \mathrm{C}$ in a temperature-controlled bath with temperature deviation of less than $1{ }^{\circ} \mathrm{C}$. After heat treatment, the samples were immediately cooled in an ice bath and directly subject to further experiments.

\section{Differential scanning calorimetry}

Differential scanning calorimetry (DSC) thermograms were recorded on a 2920 modulated DSC (TA Instruments, New Castle, DE, USA) with a heating rate of $5{ }^{\circ} \mathrm{C} / \mathrm{min}$ and temperature ranges of $25-120^{\circ} \mathrm{C}$. The instrument was calibrated for temperature and enthalpy using indium. Heated RBP were first freeze-dried, and then was placed in a hermetic aluminium pan with $15 \mathrm{mg}$ of $10 \%(\mathrm{w} / \mathrm{w}) \mathrm{RBP}$ dispersions in distilled water, and sealed. An empty pan was used as a reference. The enthalpy of denaturation $(\Delta \mathrm{H})$ and the temperature of denaturation $\left(\mathrm{T}_{\mathrm{D}}\right)$ were calculated 
using the DSC software after manually setting the start and end points of the endothermic peak.

\section{Solubility}

Samples (100 mg each) were dispersed in $10 \mathrm{ml}$ of deionised water, adjusted to $\mathrm{pH} 7.0$ using $0.1 \mathrm{M} \mathrm{HCl}$ or $\mathrm{NaOH}$. The suspensions were magnetically stirred at ambient temperature for $30 \mathrm{~min}$ and centrifuged at $3,000 \times g$ for $30 \mathrm{~min}$. Nitrogen contents of the supernatants were determined using the Lowry method (Lowry et al., 1951), and percentage nitrogen solubility was calculated as follows:

Solubility $(\%)=\frac{\begin{array}{c}\text { total protein content in } \\ \text { supernatant }\end{array}}{\begin{array}{c}\text { total protein content } \\ \text { in sample }\end{array}} \times 100 \%$

\section{Surface hydrophobicity}

The $1 \%$ globulin and $1 \%$ glutelin solutions were prepared by dissolving the proteins in $0.01 \mathrm{M}$ phosphate buffer. The $1 \%$ glutelin solution was adjusted to $\mathrm{pH} 9.0$ with $1 \mathrm{~N} \mathrm{NaOH}$. The two $1 \%$ protein solutions were then heated in a water bath at varying temperatures $\left(45\right.$ to $\left.95^{\circ} \mathrm{C}\right)$ for $10 \mathrm{~min}$. Protein solution samples were diluted to $0.00125,0.0025$, $0.005,0.01$ and $0.02 \%$ with $0.01 \mathrm{M}$ phosphate buffer. Ten $\mathrm{l}$ of 1-anilino-8-naphthalene sulfonate (ANS) solution ( $8 \mathrm{mM}$ in $0.01 \mathrm{M}$ phosphate buffer) was added to $4.0 \mathrm{ml}$ of the protein solutions immediately before measurement. Fluorescence intensity of ANS-protein conjugates was measured with a Kontron Model SF23/B spectrofluorometer (Kontron Ltd, Zurich, Switzerland) at excitation and emission wavelengths of 390 and $470 \mathrm{~nm}$, respectively. The slope of the ANS fluorescence intensity against protein concentration (\%) was calculated by linear regression and used as an index of the protein hydrophobicity.

\section{FT-IR microspectroscopy}

FT-IR absorption spectra from 4,000 to $400 \mathrm{~cm}^{-1}$ were acquired in the transmission mode by a Nicolet Magna IR 550 FT-IR spectrometer (Thermo Fisher Scientific Inc., Waltham, MA, USA) continuously purged with dry air and equipped with liquid nitrogen cooling MCT detector. Heated SPI samples were first freeze-dried, and then produced by a tablet press $(1.5 \mathrm{mg}$ protein to $200 \mathrm{mg} \mathrm{KBr}$ ) on a Carver press at 5-6 T pressure. Each spectrum was obtained by co-adding 256 interferograms at a spectrum resolution of $2.0 \mathrm{~cm}^{-1}$.

\section{Particle size distribution and zeta potential}

Particle size and zeta potential of the samples were measured using a back-scattered quasi-elastic light scattering device (Malvern Mastersizer 2000 equipped with a $100 \mathrm{~mm}$ lens, Malvern Instruments Limited, Malvern, Worcestershire,
UK, with Hydro MU sample dispersion unit). Particle size distribution (PSD) was determined from the velocity distribution of particles suspended in a dispersing medium, using the principles of dynamic light scattering.

\section{Protein electrophoresis}

Fractions of RBP were collected and separated by sodium dodecyl sulfate polyacrylamide gel electrophoresis (SDSPAGE) under reducing conditions (addition of 2.5\% $[\mathrm{v} / \mathrm{v}] \mathrm{ME})$. SDS-PAGE under non-reducing and reducing conditions was performed on $20 \%(\mathrm{w} / \mathrm{v})$ polyacrylamide gels with a PhastSystem unit (Pharmacia Biotech, Piscataway, NJ, USA), (Laemmli, 1970). All gels were silver-stained in accordance with the manufacturer's instructions (Development Technique file no. 210; Pharmacia Biotech). The freeze-dried fractions (Section 2.6) were dissolved in $40 \mu \mathrm{l}$ of sample buffer [125 mM TRIS, 4.0\% (w/v) SDS, $30 \%(\mathrm{w} / \mathrm{v})$ glycerol and $0.002 \%(\mathrm{w} / \mathrm{v})$ bromophenol blue, $\mathrm{pH} 6.8$. The samples were boiled ( $5 \mathrm{~min}$ ), and centrifuged $(11,000 \times g, 3 \mathrm{~min})$ and submitted to SDS-PAGE.

\section{Raman spectroscopic analysis}

Raman spectra were recorded on a PerkinElmer-Raman Station 400F Dispersive Raman Spectrometer (Perkin Elmer Inc., Waltham, MA, USA) equipped with a $785 \mathrm{~nm}$ diode laser. The laser was focused on the samples which were placed on microscope slides. Each spectrum was obtained under the following conditions: $80 \mathrm{~mW}$ of laser power, 4 scans, $60 \mathrm{~s}$ exposure time, $2 \mathrm{~cm}^{-1}$ resolution and the range of Raman spectra measured was $400-2,000 \mathrm{~cm}^{-1}$. Each sample was scanned at least three times, and the Raman spectra of each sample were plotted after calculating the mean. Errors in peak position were less than $\pm 3 \mathrm{~cm}^{-1}$.

Spectral data from the scans of samples were smoothed, baseline-corrected and normalised against the phenylalanine band at $1,003 \pm 1 \mathrm{~cm}^{-1}$ using the Grams 32 Software (Galactic Industries Corporation, Salem, NH, USA). The Phe band located near $1,003 \mathrm{~cm}^{-1}$ was used as internal standard to normalise the spectra, as it has been reported to be insensitive to the microenvironment. Assignment of the visible bands to vibrational modes of peptide backbone or amino acid side chains was carried out by comparing Raman spectra of model polypeptides or monographs of Raman spectra of proteins with those in the references. Quantitative estimation of secondary structure of SPI under specific conditions was performed using the PeakFit 4.12 software (SeaSolve Software, Framingham, MA, USA). Raman spectra $\left(400-2,000 \mathrm{~cm}^{-1}\right)$ were plotted as relative intensity (arbitrary units) against Raman shift in wavenumber $\left(\mathrm{cm}^{-1}\right)$. Raman spectra of each sample were collected in triplicate and the results were reported as the averages of these replicates. 


\section{Statistical analysis}

All the tests were done in triplicate and data were averaged. Standard deviation was also calculated. Student's t-test was used to evaluate significant differences $(P<0.05)$ between the means for each sample.

\section{Results and discussion}

\section{The composition of rice bran protein}

Table 1 showed the composition of RBP. Albumin and globulin are the two major RBP fractions, while prolamin is a minor component. Albumin and globulin were set as our study object; their purity was more than $80 \%$.

\section{Thermal characteristics of RBP fractions determined by DSC}

In this study, the denaturation temperature of albumin and globulin was $70.1 \pm 3.0$ and $81.3 \pm 2.3^{\circ} \mathrm{C}$, respectively, which was consistent with previously published work (Adebiyi et al., 2007). The denaturation temperature and enthalpy of denaturation seem to vary remarkably from method to method. The variation in protein concentration only brought a slight change in the endothermic peak and $\Delta \mathrm{H}$ at all heated temperatures (partly listed in Table 2). As shown in Table 2, after a thermal pre-treatment of $70^{\circ} \mathrm{C}$, the endothermic peak of albumin disappeared, indicating complete denaturation of the albumin component. The $\Delta \mathrm{H}$ of globulin declined slightly after this thermal treatment, and the $T_{D}$ was increased slightly from 81.3 to $82.6{ }^{\circ} \mathrm{C}$. Thus, the structural properties of RBP fractions were not significantly affected. Globulin denatured after a $30-\mathrm{min}$ heat treatment at $90^{\circ} \mathrm{C}$, which is closer to the $\mathrm{Td}$ of globulin.

\section{Solubility and surface hydrophobicity}

The solubility of albumin and globulin was measured as a function of applied temperature (Figure 1). Heat treatment decreased the solubility of albumin fraction sharply from $80 \%$ to $\sim 40 \%$, while the globulin fraction progressively decreased in solubility up to $100^{\circ} \mathrm{C}$ and decreased toward $110^{\circ} \mathrm{C}$. Protein denaturation of albumin resulted in the exposure of hydrophobic groups that are folded inside the intact native protein molecule, and then its solubility decreased. Heat-induced increase in surface hydrophobicity
Table 2. DSC characteristics of heat-treated RBP fractions.

\begin{tabular}{|c|c|c|c|c|}
\hline \multirow[t]{2}{*}{ Soy protein samples } & \multicolumn{2}{|l|}{ Albumin } & \multicolumn{2}{|l|}{ Globulin } \\
\hline & $\mathrm{T}_{\mathrm{D}}\left({ }^{\circ} \mathrm{C}\right)$ & $\Delta \mathrm{H}(\mathrm{J} / \mathrm{g})$ & $\mathrm{T}_{\mathrm{D}}\left({ }^{\circ} \mathrm{C}\right)$ & $\Delta \mathrm{H}(\mathrm{J} / \mathrm{g})$ \\
\hline Non-treated (control) & $70.1 \pm 3.0$ & $2.2 \pm 0.1$ & $81.3 \pm 2.3$ & $2.4 \pm 0.3$ \\
\hline Heat treatment $\left(70^{\circ} \mathrm{C}\right)$ & - & - & $82.6 \pm 1.5$ & $2.2 \pm 0.2$ \\
\hline Heat treatment $\left(80^{\circ} \mathrm{C}\right)$ & - & - & $82.2 \pm 1.6$ & $2.2 \pm 0.3$ \\
\hline Heat treatment $\left(90^{\circ} \mathrm{C}\right)$ & - & - & - & - \\
\hline
\end{tabular}

(Figure 2) provides evidence for these suggestions. It has been reported (Boye et al., 1997) that albumins from rice bran coagulated by heating like other albumins, and are readily soluble in water due to the presence of sufficient net charge and the lack of any extensive disulphide crosslinking or aggregation. But in this study, heat aggregation was found in denatured albumins due to the application of a different extraction method. In comparison, heat treatment did not significantly affect the solubility of globulin, but generally increased its surface hydrophobicity. Heating below denaturation temperature decreased the surface hydrophobicity of globulin, and then its surface hydrophobicity greatly increased up to $100{ }^{\circ} \mathrm{C}$, giving a concave curve, and then decreased toward $110^{\circ} \mathrm{C}$. The fluctuation in surface hydrophobicity, especially from 90 to $110^{\circ} \mathrm{C}$, suggested that protein denaturation of globulin exposed the hydrophobic groups and disrupted its original

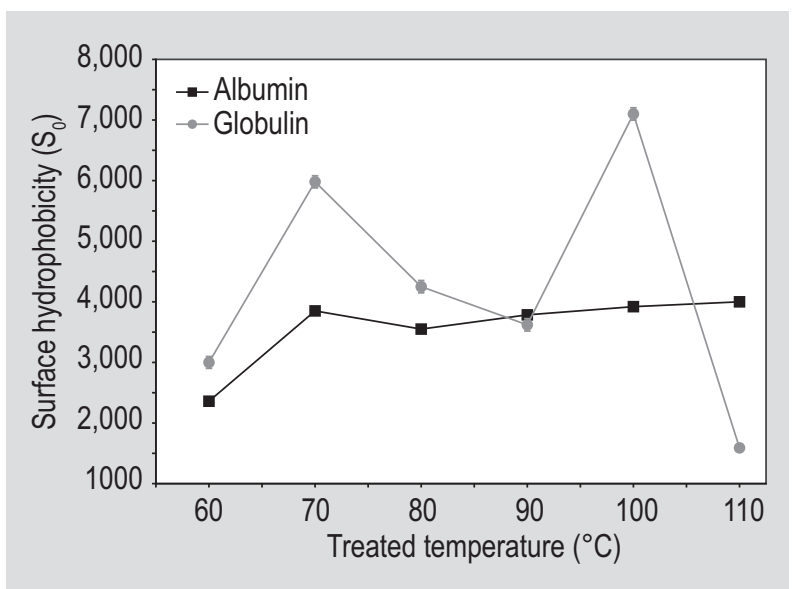

Figure 2. Surface hydrophobicity of globulin and albumin with different heat treatment.

Table 1. The composition of rice bran protein.

\begin{tabular}{|c|c|c|c|c|c|c|c|c|}
\hline \multirow[t]{2}{*}{ RBP fraction } & \multicolumn{2}{|l|}{ Albumin } & \multicolumn{2}{|l|}{ Globulin } & \multicolumn{2}{|l|}{ Prolamin } & \multicolumn{2}{|l|}{ Glutelin } \\
\hline & Yield (\%) & Purity (\%) & Yield (\%) & Purity (\%) & Yield (\%) & Purity (\%) & Yield (\%) & Purity (\%) \\
\hline Content & $40.41 \pm 0.22$ & $80.93 \pm 0.15$ & $37.43 \pm 0.42$ & $80.11 \pm 0.03$ & $3.96 \pm 0.26$ & $80.59 \pm 0.18$ & $18.34 \pm 0.09$ & $65.91 \pm 0.32$ \\
\hline
\end{tabular}


quaternary structure, leading to the dissociation of the subunits and an increase in protein-protein interactions. Thus, thermal treatment may cause more aggregates that bury more hydrophobic side chains of the amino group (Palazolo et al., 2004).

\section{Particle size distribution}

To better characterise the colloidal stability of the samples, and explain the differences in protein losses depending on the subunit composition, particle size analysis was performed. The native albumin showed a monomodal distribution of sizes with average diameter of about $134.3 \mu \mathrm{m}$, while heated albumin presented a multimodal PSD (Figure 3). The results of PSD show that heat treatment caused an increase in average particle size, widened their distribution, and significantly increased the specific free surface in all samples. The increasing amount of particles $>500 \mu \mathrm{m}$ confirmed that heat treatment induced the formation of large protein aggregates, and for this reason, the particle size decreases significantly after heating. The native globulin showed in general a larger average particle

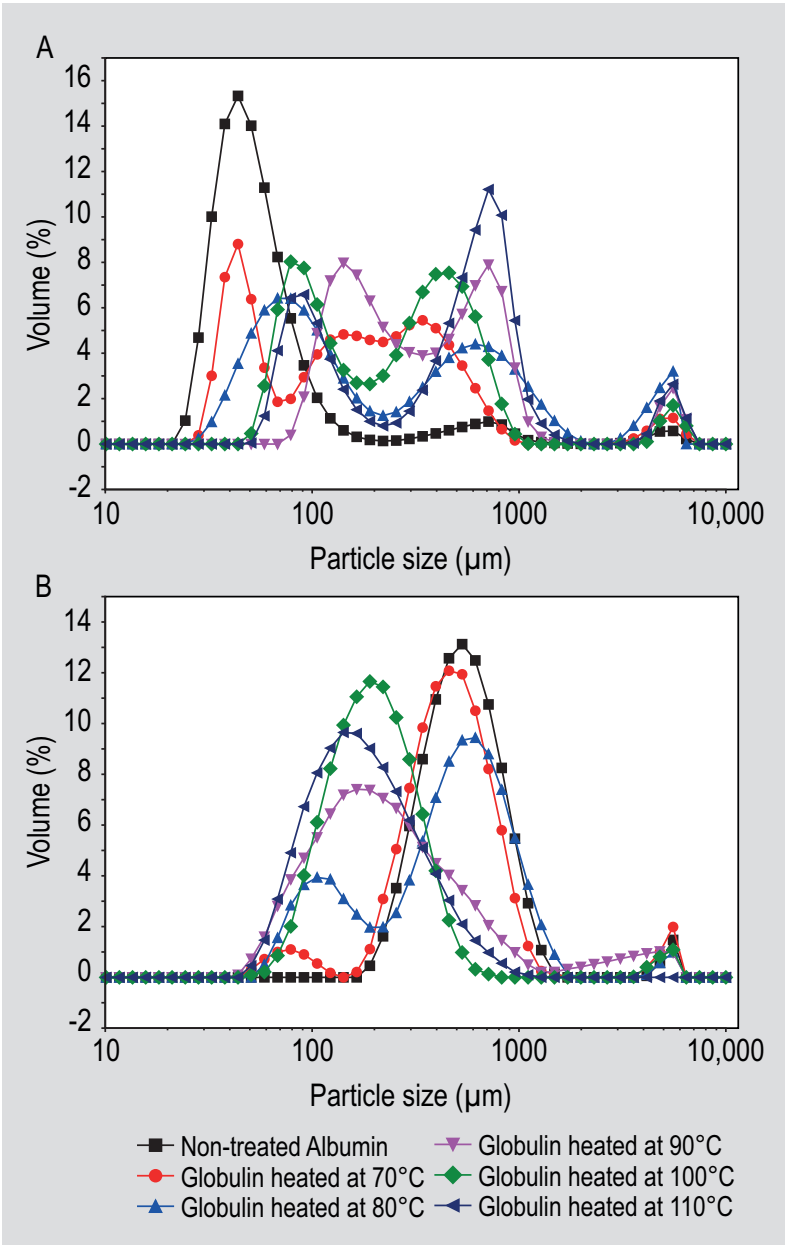

Figure 3. Particle size distribution of globulin and albumin at different temperatures. size with average diameter of about $484.7 \pm 8.3 \mu \mathrm{m}$ than heated globulin and albumin samples. Heated globulin at 70 and $80{ }^{\circ} \mathrm{C}$ showed a slightly smaller mean diameter than native globulin, but much larger than samples heated at higher temperature. Heated globulin at 70 and $80{ }^{\circ} \mathrm{C}$ increased the size of particles. When the size of particles was $150 \mu \mathrm{m}$, it was contributed to the dissociation of subunits of globulin, together with the limited denaturation of globulin (Palazolo et al., 2004). It is possible to hypothesise that dissociation of subunits leads to a decrease in surface hydrophobicity of heated globulin at 70 and $80{ }^{\circ} \mathrm{C}$. The mean particle size decreased sharply after heating globulin at $90{ }^{\circ} \mathrm{C}$ and then the size reduction gradually slowed down with the increase in applied temperature. These samples showed a wide monomodal distribution of sizes with average diameter of about 150-190 $\mu \mathrm{m}$. The shift to a smaller size distribution suggested that heat-induced denaturation of globulin aggravated the disruption of the original structure of proteins and then promoted proteinprotein interactions. Consequently, aggregation with small particle size formed, which is why the peak presented in size distribution of denatured globulin became wider. The smaller particle size was considered to be the polypeptide chains of rice globulins stabilised by interchain disulphide bonds (Hamada, 1997) that were broken by heating.

\section{Zeta potential}

Dependence of the zeta potential on the applied temperature is shown in Figure 4. It can be seen that absolute zeta potential of the treated rice bran albumin suspensions decreased in general with the increased applied temperature. Low absolute value of zeta potential reduced the repulsive electrostatic force between the molecules, and promoted the protein aggregates formation (as shown in Figure 5). Therefore, it can be reasonably inferred that a decrease of electrostatic repulsive forces between the molecules would oppose an increase of their solubility and other solubility-related functional properties. The absolute value of zeta potential increased to $80{ }^{\circ} \mathrm{C}$, then decreased toward $110{ }^{\circ} \mathrm{C}$. This could be indicative of increased exposure of negatively charged and/or hydrophobic regions and subunits dissociation induced by heat treatment at 70 and $80^{\circ} \mathrm{C}$. In contrast, the decrease in absolute value of zeta potential is most likely due to protein aggregation by denatured globulin.

Overall, the zeta-potential analysis indicates that in most cases zeta-potential values were above the threshold of agglomeration $(-10 \mathrm{mV})$, suggesting that the studied protein systems were relatively stable under the experimental conditions of this study, and globulin heated at temperatures above $100{ }^{\circ} \mathrm{C}$ seemed prone to aggregation. 


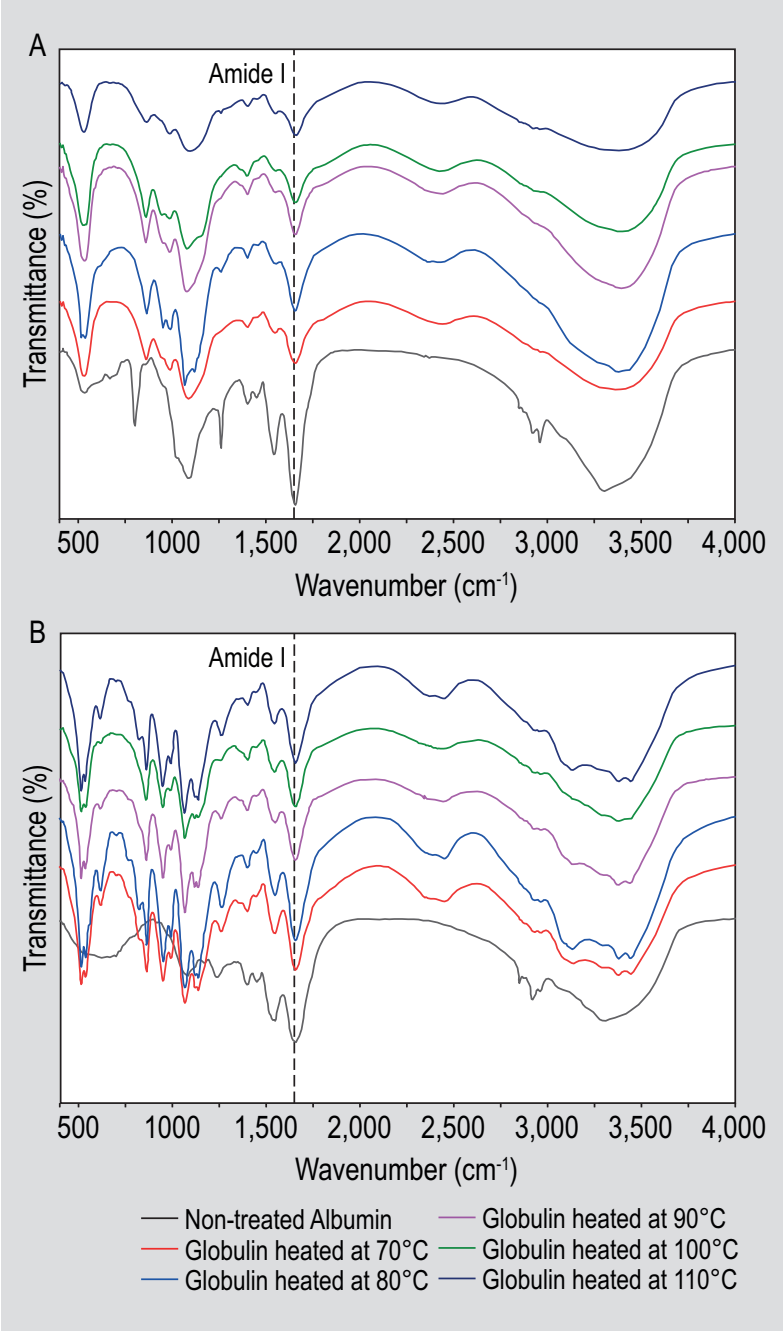

Figure 4. FT-IR spectrum of globulin and albumin with different heat treatment.

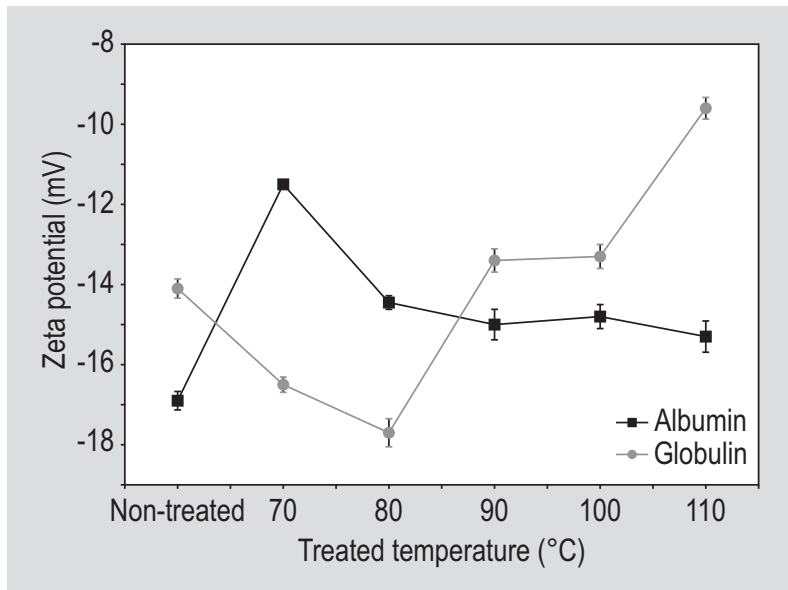

Figure 5. Zeta potential of globulin and albumin with different heat treatment.

\section{FT-IR microspectroscopy}

Figure 6 shows FT-IR spectra of RBP with different temperature of heat treatment; both albumin and globulin showed peaks at 560, 758, 1,089, 1,660, 2,370, and a broad peak around $3,400 \mathrm{~cm}^{-1}$ which was associated with $\mathrm{O}-\mathrm{H}$ stretching vibrations, and it became broader with increasing temperature, indicating the formation of more $\mathrm{OH}$ groups (El-Shafey, 2005). The amide I (marked in Figure 4) mode originates mainly from the $\mathrm{C}=\mathrm{O}$ stretching vibration of the polypeptide backbone (Barth, 2007). The major factors responsible for the conformational specificity of the amide I band are its sensitivity to hydrogen bonding and the characteristic coupling between transition dipoles, the latter leading to characteristic splitting effects. The magnitude of this splitting depends on the orientation and distance of interacting dipoles and thus provides information about the geometrical arrangements of peptide groups in a polypeptide chain.

The areas of assigned amide I bands in the second derivative spectra correspond linearly to the amount of the different types of secondary structures present in the protein. In this study, prior to the second-derivative analysis, a baseline adjustment was performed to accurately measure the band areas of second derivative spectra in amide I and further study of Fourier self-deconvolution (FSD), which can substantially influence the number, position and intensity of the bands resolved by a Gaussian curve fit (GCF) (Goormaghtigh et al., 1994). The GCF was adjusted to give the best least squares fit of the individual bands to each deconvoluted spectrum, followed by a secondderivative analysis. In this analysis, we combined FSD, second-derivative and GCF to quantitatively analyse the second derivative of the spectra (Figure 7). Our secondderivative band positions followed with previous data from the literature that reported a strong band for $\alpha$-helix with a frequency around 1,650-1,660 $\mathrm{cm}^{-1}$. We also obtained several bands corresponding to $\beta$-sheet in the frequency region of $1,618-1,640 \mathrm{~cm}^{-1}$ and 1,680-1,700 $\mathrm{cm}^{-1}$. A series of bands corresponding to $\beta$-turn appeared in the 1,660 $1,680 \mathrm{~cm}^{-1}$ range. The random coil structure had a strong band close to $1,645 \mathrm{~cm}^{-1}$.

The percentages of $\alpha$-helix, $\beta$-sheet, unordered and $\beta$-turn secondary structures in RBP are shown in Table 3 . The secondary structure composition of albumin was 19.29\% $\alpha$-helix, 34.54\% $\beta$-sheet, $25.95 \%$ turns and $20.23 \%$ random coil, while that of globulin was $18.15 \% \alpha$-helix, $38.56 \% \beta$-sheet, $23.69 \%$ turns and $19.59 \%$ random coil. The major changes observed during heating at $70{ }^{\circ} \mathrm{C}$ were a pronounced transition to more $\beta$-turn and random coil structures and a shift toward lower wavenumbers, suggesting protein structure reorganisation by extensive unfolding and thermal denaturation. The percentages of the bands associated with $\alpha$-helix and $\beta$-sheet structures 


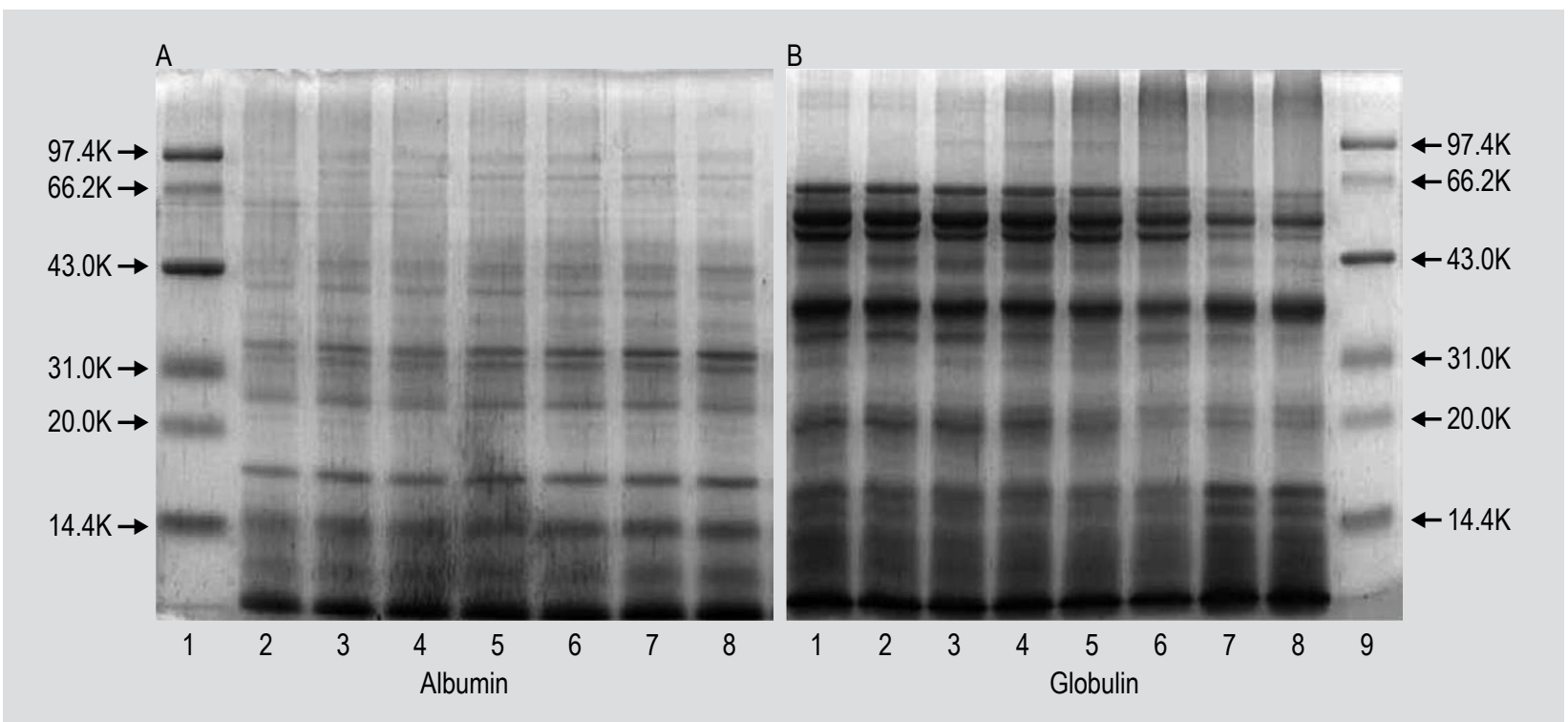

Figure 6. Effect of temperature on SDS-PAGE profile of rice bran albumin and globulin. (A) 1, marker; $2,110^{\circ} \mathrm{C} ; 3,100^{\circ} \mathrm{C} ; 4$, $90^{\circ} \mathrm{C} ; 5,80^{\circ} \mathrm{C} ; 6,70^{\circ} \mathrm{C} ; 7,60^{\circ} \mathrm{C} ; 8$, room temperature. (B) 1 , room temperature; $2,60^{\circ} \mathrm{C} ; 3,70^{\circ} \mathrm{C} ; 4,80^{\circ} \mathrm{C} ; 5,90^{\circ} \mathrm{C} ; 6,100^{\circ} \mathrm{C}$; $7,110^{\circ} \mathrm{C} ; 8,110^{\circ} \mathrm{C} ; 9$, marker.

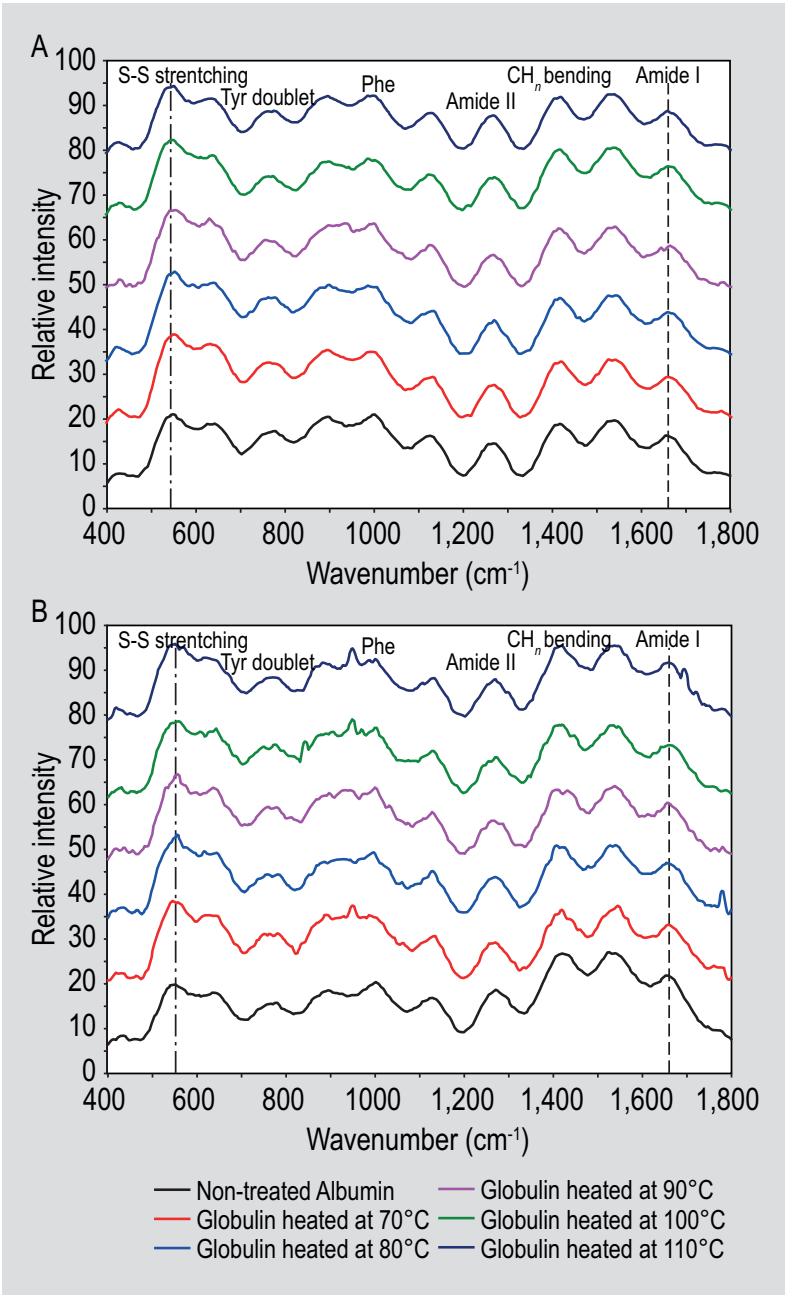

Figure 7. Raman spectrum of globulin and albumin with different heat treatment. increased upon heating, while the pronounced increase in $\alpha$-helix and $\beta$-sheet structures from random coil and $\beta$-turn structures suggest further development of aggregate structures by heating. In this study, the spectral contributions detected in the 1,610-1,615 $\mathrm{cm}^{-1}$ and 1,690$1,695 \mathrm{~cm}^{-1}$ ranges were recorded, which may be assigned to protein aggregates as well as to absorption of amino acid side-chains (Barth, 2007; Murayama and Tomida, 2004). Moreover, high frequency contributions around $1,690 \mathrm{~cm}^{-1}$ have been found to increase in gliadins subjected to heat treatments and unambiguously associated to intermolecular protein aggregation (Secundo and Guerrieri, 2005). The presence of a low-frequency band at 1,610-1,620 $\mathrm{cm}^{-1}$ has been addressed as a marker for intermolecular protein complexes (Marina et al., 2008). As shown in Table 3, the intensities of the aggregated strands $\left(1,616\right.$ and $\left.1,685 \mathrm{~cm}^{-1}\right)$ progressively increased with increasing temperature, indicating association/aggregation (Boye et al., 1997) and subsequent dissociation.

In contrast, heating globulin generally increased the content of $\alpha$-helix and $\beta$-turn structure, but reduced $\beta$-sheet and random coil structures. This transformation indicates protein structure reorganisation by subunit dissociation and aggregation and heat denaturation. The decrease in content of bands at 1,610-1,615 $\mathrm{cm}^{-1}$ and 1,690-1,695 $\mathrm{cm}^{-1}$ in heated globulin at 70 and $80^{\circ} \mathrm{C}$ may be attributed to the dissociation of subunits, confirming the PSD analysis. 
Table 3. Secondary structure composition of rice bran proteins as calculated from Amide I bands of FT-IR spectra using PeakFit software (SeaSolve Software, Framingham, MA, USA). ${ }^{1}$

\begin{tabular}{llllll} 
Sample & & a-helix (\%) & $\beta$-sheet (\%) & $\beta$-turn (\%) & Random coil (\%) \\
Albumin & Non-treated sample & $19.29 \pm 0.05 \mathrm{~b}$ & $34.54 \pm 0.07 \mathrm{e}(8.56 \pm 0.01)$ & $25.95 \pm 0.06 \mathrm{~b}$ & $20.23 \pm 0.03 \mathrm{c}$ \\
& Heat treatment $\left(70^{\circ} \mathrm{C}\right)$ & $18.81 \pm 0.02 \mathrm{a}$ & $30.20 \pm 0.04 \mathrm{a}(8.74 \pm 0.02)$ & $28.76 \pm 0.07 f$ & $22.23 \pm 0.08 \mathrm{~d}$ \\
& Heat treatment $\left(80^{\circ} \mathrm{C}\right)$ & $19.78 \pm 0.01 \mathrm{c}$ & $30.97 \pm 0.05 \mathrm{~b}(9.13 \pm 0.02)$ & $27.07 \pm 0.02 \mathrm{e}$ & $22.18 \pm 0.06 \mathrm{~d}$ \\
& Heat treatment $\left(90^{\circ} \mathrm{C}\right)$ & $19.77 \pm 0.02 \mathrm{c}$ & $32.67 \pm 0.01 \mathrm{c}(10.29 \pm 0.01)$ & $26.86 \pm 0.02 \mathrm{~d}$ & $20.70 \pm 0.04 \mathrm{a}$ \\
& Heat treatment $\left(100^{\circ} \mathrm{C}\right)$ & $20.77 \pm 0.10 \mathrm{e}$ & $33.99 \pm 0.04 \mathrm{~d}(12.87 \pm 0.03)$ & $25.21 \pm 0.07 \mathrm{a}$ & $20.03 \pm 0.03 \mathrm{~b}$ \\
& Heat treatment $\left(110^{\circ} \mathrm{C}\right)$ & $20.30 \pm 0.02 \mathrm{~d}$ & $33.73 \pm 0.01 \mathrm{f}(13.45 \pm 0.03)$ & $26.29 \pm 0.02 \mathrm{c}$ & $19.68 \pm 0.01 \mathrm{a}$ \\
\multirow{3}{*}{ Globulin } & Non-treated sample & $18.15 \pm 0.02 \mathrm{a}$ & $38.56 \pm 0.03 \mathrm{f}(12.45 \pm 0.03)$ & $23.69 \pm 0.04 \mathrm{~b}$ & $19.59 \pm 0.03 \mathrm{c}$ \\
& Heat treatment $\left(70^{\circ} \mathrm{C}\right)$ & $19.35 \pm 0.01 \mathrm{~b}$ & $37.00 \pm 0.07 \mathrm{e}(11.37 \pm 0.03)$ & $23.89 \pm 0.08 \mathrm{c}$ & $19.76 \pm 0.06 \mathrm{~d}$ \\
& Heat treatment $\left(80^{\circ} \mathrm{C}\right)$ & $19.39 \pm 0.09 \mathrm{~b}$ & $36.99 \pm 0.08 \mathrm{~d}(11.89 \pm 0.01)$ & $24.33 \pm 0.07 \mathrm{~d}$ & $19.29 \pm 0.08 \mathrm{a}$ \\
& Heat treatment $\left(90^{\circ} \mathrm{C}\right)$ & $19.50 \pm 0.06 \mathrm{c}$ & $35.68 \pm 0.02 \mathrm{~b}(12.67 \pm 0.02)$ & $25.44 \pm 0.01 \mathrm{e}$ & $19.39 \pm 0.05 \mathrm{~b}$ \\
& Heat treatment $\left(100^{\circ} \mathrm{C}\right)$ & $19.78 \pm 0.07 \mathrm{~d}$ & $35.37 \pm 0.06 \mathrm{a}(12.89 \pm 0.03)$ & $25.47 \pm 0.08 \mathrm{e}$ & $19.37 \pm 0.03 \mathrm{~b}$ \\
& Heat treatment $\left(110^{\circ} \mathrm{C}\right)$ & $20.73 \pm 0.01 \mathrm{e}$ & $36.38 \pm 0.01 \mathrm{c}(12.97 \pm 0.01)$ & $23.58 \pm 0.00 \mathrm{a}$ & $19.31 \pm 0.02 \mathrm{a}$ \\
\hline
\end{tabular}

${ }^{1}$ Different letters within the same column indicate statistically significant differences among samples $(P<0.05)$. Date are means \pm standard deviation of triplicates.

${ }^{2}$ The values between brackets represent the percentage of bands at $1,610-1,615 \mathrm{~cm}^{-1}$ and $1,690-1,695 \mathrm{~cm}^{-1}$.

\section{SDS-PAGE patterns of RBPF}

The protein patterns of each method were successfully examined by SDS-PAGE as shown in Figure 6. Albumin had bands around 33, 25, 18 and $14 \mathrm{kDa}$ regions, while globulin showed protein patterns with 50, 36 and $20 \mathrm{kDa}$ regions. Abyomi (2009) had a similar result, reporting that the molecular weights of rice bran albumin have bands around 31-45, while globulin showed bands around 33 and $53 \mathrm{kDa}$. Hamada (1997) reported the molecular weights of albumin and globulin to be in the range 10-100 and $10-150 \mathrm{kDa}$, respectively. It can be seen from Figure 8 that the relative band intensity of albumin around $33 \mathrm{kDa}$ regions decreased with heating; in contrast, the relative band intensity around $45-53 \mathrm{kDa}$ increased. This indicated the formation of heating aggregation, which is in accordance with the findings in PSD. It seemed that heating below $80{ }^{\circ} \mathrm{C}$ did not change the SDS-PAGE pattern, but notable losses in bands around 20 and $50 \mathrm{kDa}$ were observed when heating up to $90{ }^{\circ} \mathrm{C}$. This provides further evidence that heating denaturation dissociated the subunits of globulin. The appearance of bands on the top of SDS-PAGE pattern with a molecular weight around $70 \mathrm{kDa}$ may be attributed to the heat-aggregation of globulin by dissociated subunits.
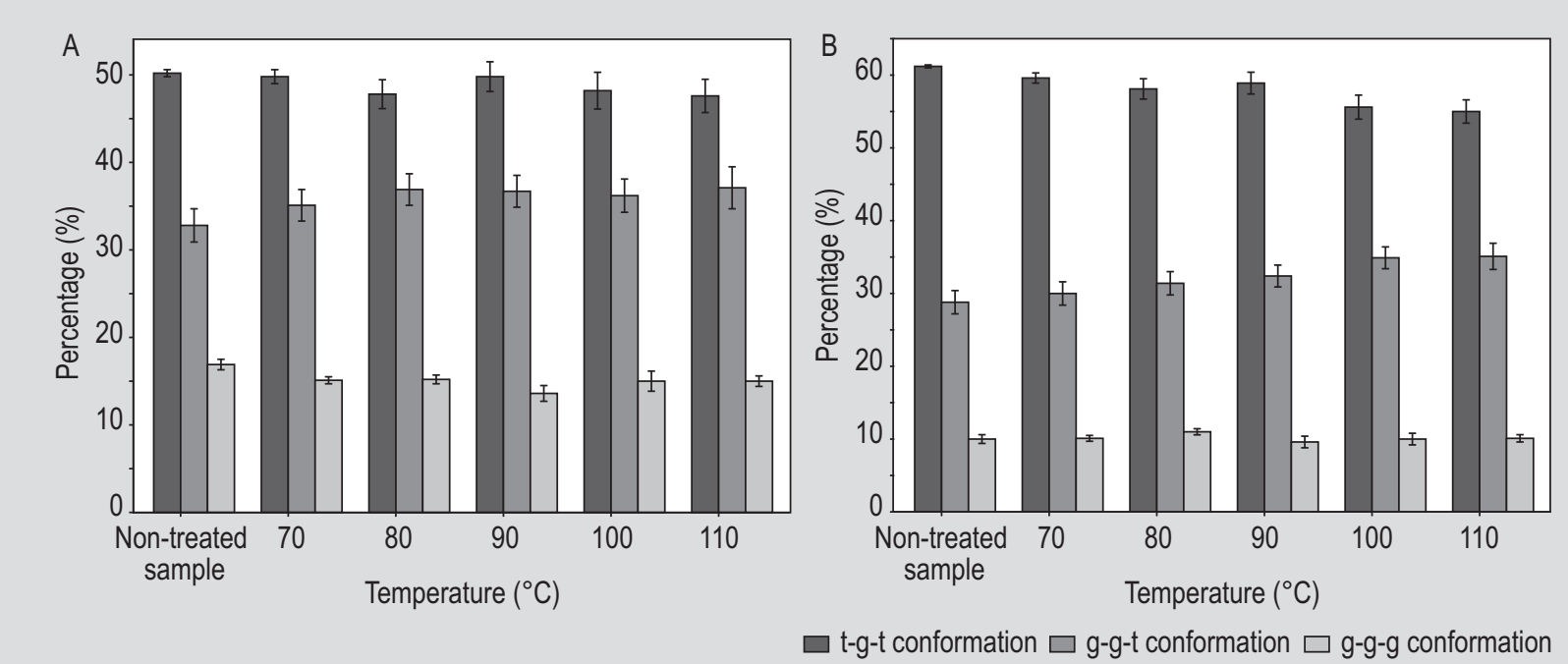

Figure 8. Conformation of disulphide bonds in globulin and albumin with different heat treatment analysed by Raman spectrum. 


\section{Raman spectroscopic analysis}

The Raman spectra of RBP upon heating at different temperatures are shown in Figure 7. The assignments of some major bands (Table 4) were made based on previous works (Moon and Li-Chan, 2007). The frequency and intensity changes in the Raman bands were mainly indicative of changes in the secondary structure and variations in local environments of RBP.

The secondary structure of RBP was mainly determined by the Raman characteristic peaks of amide I band with ACD/Labs software (ACD/Labs, Toronto, Canada). Results (Table 2) showed that albumin contained 29.54\% $\alpha$-helix, $26.02 \% \beta$-sheet, $15.05 \%$ turns and $29.39 \%$ unordered structures, while globulin was composed of $26.25 \% \alpha$-helix, $32.90 \% \beta$-sheet, $14.89 \%$ turns and $25.96 \%$ unordered structures (Table 5). Compared with FT-IR, the result analysed by Raman showed a lower content of $\beta$-turn structure and a higher percentage of $\alpha$-helix, but the secondary structure percentages determined by Raman showed similar trends to FT-IR, confirmed by the above discussion.

The ratio of albumin and globulin both ranged from 0.93 to 1.08 in this experiment, which suggested that the tyrosine residues were exposed to the aqueous or polar microenvironment or act as simultaneous acceptor and donor of moderate to weak hydrogen bonds regardless

Table 4. Tentative assignment of some bands in the Raman spectrum of rice bran protein.

\begin{tabular}{|c|c|}
\hline Frequency $\left(\mathrm{cm}^{-1}\right)$ & Assignment $^{1}$ \\
\hline 514 & vS-S gauche-gauche-gauche conformation \\
\hline 530 & vS-S gauche-gauche-trans conformation \\
\hline 547 & vS-S trans-gauche-trans conformation \\
\hline $620-640$ & Phe \\
\hline 644 & Tyr \\
\hline 760 & Trp \\
\hline 830 & Tyr v-ring \\
\hline 850 & Tyr v-ring \\
\hline 940 & $v C C(\alpha$-helix) \\
\hline 1,003 & Phe v-ring \\
\hline 1,250 & Amide III ( $\beta$-sheets, random coil) \\
\hline 1,273 & Amide III ( $\alpha$-helix) \\
\hline 1,309 & Amide III ( $\alpha$-helix) \\
\hline 1,321 & Trp v-ring \\
\hline 1,340 & $\delta \mathrm{CH}$ \\
\hline 1,360 & Trp v-ring \\
\hline 1,450 & $\delta_{\mathrm{as}} \mathrm{CH}_{3}, \delta \mathrm{CH}_{2}, \delta \mathrm{CH}$ \\
\hline $1,645-1,690$ & Amide I \\
\hline
\end{tabular}

of heat-treatment procedure applied. It can be deduced from Table 6 that Tyr doublet ratios of albumin tended to decrease when compared with non-treated samples, which indicated heating albumin increasing buriedness or involvement of Tyr residues as weak hydrogen bonds acceptor or donor. In contrast, Tyr doublet ratio decreased when heated globulin is below $90^{\circ} \mathrm{C}$, but increased up to $90{ }^{\circ} \mathrm{C}$. It can be deduced that the increase in Tyr doublet ratio contributed to denaturation of globulin, meanwhile, the decrease in Tyr doublet ratio may be related to the buriedness of hydrophobic Tyr by aggregation formation.

The band assigned to the $\mathrm{CH}_{2}$ and $\mathrm{CH}_{3}$ bending vibrations observed near $1,450 \mathrm{~cm}^{-1}$ was studied. As shown in Table 6 , a general tendency of intensity decreasing in $1,450 \mathrm{~cm}^{-1}$ band of albumin was observed, indicating that more hydrophobic groups are exposed to polar environment. Heating increased surface hydrophobicity and more exposed Trp both proved the reduction in the intensity of this band. Whereas, no distinct variation was found in $1,450 \mathrm{~cm}^{-1}$ band of globulin, it can be deduced that variation of $1,450 \mathrm{~cm}^{-1}$ band mainly followed with Trp band that is produced by the hydrolysis of amino acids.

The $500-560 \mathrm{~cm}^{-1}$ band range is attributed to disulphide bonds formed by bridging the thiol groups of two cysteine molecules. Protein and peptides containing cystine residues usually show a band in the Raman spectrum near $510 \mathrm{~cm}^{-1}$ which has been assigned to S-S stretching vibrations of disulphide bonds in the lowest potential energy conformation, that is, in the gauche-gauche-gauche $(g-g-g)$ conformation. The bands at 525 and $540 \mathrm{~cm}^{-1}$ have been assigned to gauche-gauche-trans $(g-g-t)$ and trans-gauchetrans $(t-g-t)$ conformations, respectively. The main peak near $540 \mathrm{~cm}^{-1}$ in Raman spectra of globulin and albumin indicated that the $t-g-t$ conformation of the intermolecular disulphide bond is gradually formed (Ellepola et al., 2006). In order to determine the vibration mode assignments of the disulphide bonds, Multi-peak Gaussian fitting performed by Peak Analyzer was used to fit the curve; the fitted results are listed in Figure 8. It can be concluded from Figure 8 (A) that heating albumin decreased the content of $t-g-t$ and $g-g-g$ conformation but increased $g-g-t$ conformation, the transformation from $t-g-t$ and $g-g-g$ conformation to $g$-g-t conformation became fiercer with increased heating temperature. Figure 8 (B) showed that heating globulin induced a sharp reduction in content of $t$ - $g$ - $t$ conformation that transformed to $g-g-g$ and $g-g-t$ conformation. The loss in $t-g-t$ conformation confirmed heating dissociated subunits of albumin and globulin, for $t-g$ - $t$ conformation is a formation of intermolecular disulphide linkages. The content of $g-g-g$ conformation decreased when heating denatured globulin above $90^{\circ} \mathrm{C}$, while decreased content of $g-g-g$ conformation was also observed in denatured albumin, which indicated that denaturation of protein destroys the $g-g-g$ conformation mainly for $g-g-g$ conformation of 
Table 5. Secondary structure composition of rice bran proteins as calculated from Amide I bands of Raman spectra using PeakFit software (SeaSolve Software, Framingham, MA, USA). ${ }^{1}$

\begin{tabular}{|c|c|c|c|c|c|}
\hline Sample & & a-helix (\%) & $\beta$-sheet (\%) & $\beta$-turn (\%) & Random coil (\%) \\
\hline \multirow[t]{6}{*}{ Albumin } & Non-treated sample & $29.54 \pm 0.05 d$ & $26.02 \pm 0.03 e$ & $15.05 \pm 0.04 c$ & $29.39 \pm 0.01 b$ \\
\hline & Heat treatment $\left(70^{\circ} \mathrm{C}\right)$ & $25.03 \pm 0.03 a$ & $23.80 \pm 0.04 a$ & $19.97 \pm 0.03 e$ & $30.21 \pm 0.02 d$ \\
\hline & Heat treatment $\left(80^{\circ} \mathrm{C}\right)$ & $27.11 \pm 0.02 b$ & $24.70 \pm 0.01 b$ & $18.55 \pm 0.03 d$ & $29.64 \pm 0.01 \mathrm{c}$ \\
\hline & Heat treatment $\left(90^{\circ} \mathrm{C}\right)$ & $28.95 \pm 0.02 \mathrm{c}$ & $25.30 \pm 0.02 c$ & $15.11 \pm 0.02 c$ & $30.63 \pm 0.01 f$ \\
\hline & Heat treatment $\left(100^{\circ} \mathrm{C}\right)$ & $30.46 \pm 0.03 e$ & $25.77 \pm 0.03 d$ & $13.25 \pm 0.04 b$ & $30.52 \pm 0.01 \mathrm{e}$ \\
\hline & Heat treatment $\left(110^{\circ} \mathrm{C}\right)$ & $30.92 \pm 0.02 f$ & $28.70 \pm 0.06 f$ & $12.85 \pm 0.05 a$ & $27.52 \pm 0.04 a$ \\
\hline \multirow[t]{6}{*}{ Globulin } & Non-treated sample & $26.25 \pm 0.03 a$ & $32.90 \pm 0.04 f$ & $14.89 \pm 0.03 a$ & $25.96 \pm 0.02 d$ \\
\hline & Heat treatment $\left(70^{\circ} \mathrm{C}\right)$ & $28.49 \pm 0.02 c$ & $31.30 \pm 0.02 d$ & $15.00 \pm 0.02 b$ & $25.21 \pm 0.03 a$ \\
\hline & Heat treatment $\left(80^{\circ} \mathrm{C}\right)$ & $28.35 \pm 0.01 b$ & $31.47 \pm 0.01 \mathrm{e}$ & $14.94 \pm 0.01 \mathrm{a}$ & $25.24 \pm 0.00 \mathrm{a}$ \\
\hline & Heat treatment $\left(90^{\circ} \mathrm{C}\right)$ & $28.38 \pm 0.00 \mathrm{~b}$ & $30.69 \pm 0.02 c$ & $15.66 \pm 0.02$ & $25.28 \pm 0.04 a$ \\
\hline & Heat treatment $\left(100^{\circ} \mathrm{C}\right)$ & $28.88 \pm 0.04 d$ & $29.92 \pm 0.02 b$ & $15.65 \pm 0.02$ & $25.55 \pm 0.03 b$ \\
\hline & Heat treatment $\left(110^{\circ} \mathrm{C}\right)$ & $29.44 \pm 0.02 \mathrm{e}$ & $29.79 \pm 0.03 a$ & $15.00 \pm 0.03 b$ & $25.77 \pm 0.01 \mathrm{c}$ \\
\hline
\end{tabular}

${ }^{1}$ Different superscript letters in the same column indicate significant differences $(P<0.05)$.

Table 6. Normalised intensities of the tryptophan band $\left(759 \mathrm{~cm}^{-1}\right)$, tyrosyl doublet $\left(850 / 830 \mathrm{~cm}^{-1}\right), \delta \mathrm{CH}$ band $\left(1,450 \mathrm{~cm}^{-1}\right)$ of rice bran protein with different heat treatment. ${ }^{1}$

\begin{tabular}{|c|c|c|c|c|}
\hline Sample & & $\operatorname{Trp}$ band $^{2}\left(\mathrm{I}_{760} / \mathrm{I}_{1,003} \mathrm{~cm}^{-1}\right)$ & Tyr doublet $\left(\mathrm{I}_{850} / \mathrm{I}_{830} \mathrm{~cm}^{-1}\right)$ & $\mathrm{CH}$ band $\left(\mathrm{I}_{1,450} \mathrm{I}_{1,003} \mathrm{~cm}^{-1}\right)$ \\
\hline \multirow[t]{6}{*}{ Albumin } & Non-treated sample & $0.98 \pm 0.01 b$ & $1.01 \pm 0.01 b$ & $0.98 \pm 0.00 \mathrm{~b}$ \\
\hline & Heat treatment $\left(70^{\circ} \mathrm{C}\right)$ & $0.90 \pm 0.01 \mathrm{a}$ & $0.95 \pm 0.02 a$ & $0.93 \pm 0.01 a$ \\
\hline & Heat treatment $\left(80^{\circ} \mathrm{C}\right)$ & $0.89 \pm 0.02 a$ & $0.94 \pm 0.01 \mathrm{a}$ & $0.94 \pm 0.01 a$ \\
\hline & Heat treatment $\left(90^{\circ} \mathrm{C}\right)$ & $0.91 \pm 0.01 a$ & $0.97 \pm 0.01 a$ & $0.92 \pm 0.01 a$ \\
\hline & Heat treatment $\left(100^{\circ} \mathrm{C}\right)$ & $0.90 \pm 0.01 \mathrm{a}$ & $0.93 \pm 0.01 \mathrm{a}$ & $0.94 \pm 0.01 a$ \\
\hline & Heat treatment $\left(110^{\circ} \mathrm{C}\right)$ & $0.89 \pm 0.00 a$ & $0.96 \pm 0.00 a$ & $0.95 \pm 0.01 a$ \\
\hline \multirow[t]{6}{*}{ Globulin } & Non-treated sample & $0.96 \pm 0.00 a$ & $1.01 \pm 0.01 b$ & $1.02 \pm 0.02 a$ \\
\hline & Heat treatment $\left(70^{\circ} \mathrm{C}\right)$ & $0.96 \pm 0.02 a$ & $0.98 \pm 0.01 \mathrm{a}$ & $1.01 \pm 0.01 \mathrm{a}$ \\
\hline & Heat treatment $\left(80^{\circ} \mathrm{C}\right)$ & $0.96 \pm 0.01 a$ & $0.95 \pm 0.02 a$ & $1.00 \pm 0.01 a$ \\
\hline & Heat treatment $\left(90^{\circ} \mathrm{C}\right)$ & $0.96 \pm 0.03 a$ & $1.04 \pm 0.01 b c$ & $0.99 \pm 0.03 a$ \\
\hline & Heat treatment $\left(100^{\circ} \mathrm{C}\right)$ & $0.95 \pm 0.02 a$ & $1.03 \pm 0.02 b c$ & $0.99 \pm 0.02 a$ \\
\hline & Heat treatment $\left(110^{\circ} \mathrm{C}\right)$ & $0.96 \pm 0.02 a$ & $1.08 \pm 0.01 \mathrm{c}$ & $1.02 \pm 0.01 a$ \\
\hline
\end{tabular}

the intramolecular disulphide bonds. Additionally, the increasing content of $g-g-t$ conformation may contribute to the formation of heating aggregation.

\section{Conclusions}

The effect of heat treatment on solubility, surface hydrophobicity and structure of rice bran albumin and globulin as major components in RBP was studied. Heating decreased the solubility of albumin and globulin, mainly due to protein denaturation induced increasing surface hydrophobicity and exposed hydrophobic groups, formation of heat aggregation by dissociated subunits, higher particle size aggregated by subunits. Both results from FT-IR and Raman spectrum confirmed the above-mentioned discussion; structure reorganisation and aggregation were proofed by variation in the content of secondary structure elements and micro-environment of side chain. In addition, the loss of intermolecular $t-g-t$ and $g-g-g$ conformation of $S-S$ stretching vibrations verified subunits dissociation and structure damage by denaturation. We hope this work will play a positive role in improving the solubility of RBP and analysing the internal structure of albumin and globulin. 


\section{Acknowledgements}

This work was supported by the National natural science funding project (31101387), 'Twelfth Five-year' national science and technology support project (2012BAD34B00), Heilongjiang Province Postdoctoral Science Foundation (Grant number: LBH-Z15217) Science and Technology Research Project of Heilongjiang Agricultural Reclamation Administration (Grant number: HNK135-05-01).

\section{Conflict of interest}

The authors declare that they have no conflict of interest.

\section{Compliance with ethical standards}

This article does not contain any studies with human participants or animals performed by any of the authors. Informed consent was obtained from all individual participants included in the study.

\section{Reference}

Adebiyi, A.P., Adebiyi, A.O., Hasegawa, Y., Ogawa, T. and Muramoto, K., 2009. Isolation and characterization of protein fractions from deoiled rice bran. European Food Research and Technology 228: 391-401.

Adebiyi, A.P., Adebiyi, A.O., Ogawa, T. and Muramoto K., 2007. Preparation and characterization of high-quality rice bran proteins. Journal of the Science of Food and Agriculture 87: 1219-1227.

Barth, A., 2007. Infrared spectroscopy of proteins. Biochimica et Biophysica Acta 1767: 1073-1101.

Boye, J.I., Mar, C.Y. and Harwalkar, V.R., 1997. Thermal denaturation and coagulation of protein. In: Damodaran S. and Paraf, A. (eds.) Food proteins and their applications. Marcel Dekker, New York, NY, USA, pp. 25-56.

Chandi, G.K., 2008. Effect of extraction temperature on functional properties of rice bran protein concentrates. International Journal of Food Engineering 4: 99-107.

Daussant, J., Mosse, J. and Vaughan, J., 1983. Seed proteins. Annual Proceedings of the Phytochemical Society of Europe. Academic Press, New York, NY, USA.

Ellepola, S.W., Choi, S.M., Phillips, D.L. and Ma, C.Y., 2006. Raman spectroscopic study of rice globulin. Journal of Cereal Science 43: 85-93.

El-Shafey, E.I., 2005. Behavior of reduction-sorption of Chromium (VI) from an aqueous solution on a modified sorbent from rice husk. Water Air and Soil Pollution 163(1-4): 81-102.

Goormaghtigh, E., Cabiaux, V. and Ruysschaert, J.M., 1994. Determination of soluble and membrane protein structure by Fourier transform infrared spectroscopy. II. Experimental aspects, side chain structure, and H/D exchange. Subcellular Biochemistry 23: 363-403.
Hamada, J.S., 1997. Characterization of protein fractions of rice bran to devise effective methods of protein solubilization. Cereal Chemistry 74: 662-668.

Helm, R.M. and Burks, A.W., 1996. Hypoallergenicity of rice bran protein. Cereal Foods World 41: 839-843.

Ju, Z.Y., Hettiarachchy, N.S. and Rath, N., 2001. Extraction, denaturation and hydrophobic properties of rice flour proteins. Journal of Food Science 66: 229-232.

Juliano, B.O., 1985. Polysaccharides, proteins, and lipids of rice. Rice: Chemistry and Technology. American Association of Cereal Chemists, Eagan, MN, USA, pp. 59-174.

Kennedy, G. and Burlingame, B., 2003. Analysis of food composition data on rice from a plant genetic resources perspective. Food Chemistry 80: 589-596.

Laemmli, U.K., 1970. Cleavage of structural proteins during the assembly of the head of bacteriophage T4. Nature 227: 680-685.

Lowry, O.H., Rosebrough, N.J., Farr, A.L. and Randall, R.J., 1951. Protein measurement with the Folin phenol reagent. Journal of Biological Chemistry 193: 265-275.

Marina, C., Paola, M., Paolo, D. and Alessandro, N., 2008. Application of Fourier transform infrared spectroscopy to legume seed flour analysis. Food Chemistry 108: 361-368.

Moon, S.Y. and Li-Chan, E.C.Y., 2007. Assessment of added ingredient effect on interaction of simulated beef flavour and soy protein isolate by gas chromatography, spectroscopy and descriptive sensory analysis. Food Research International 40: 1227-1238.

Murayama, K. and Tomida, M., 2004. Heat-induced secondary structure and conformation change of bovine serum albumin investigated by Fourier transform infrared spectroscopy. Biochemistry 43: 115261153.

Palazolo, G.G., Sorgentini, D.A. and Wagner, J.R., 2004. Emulsifying properties and surface behavior of native and denatured whey soy proteins in comparison with other proteins: creaming stability of oil-in-water emulsion. Journal of the American Oil Chemistry Society 81: 625-632.

Saunders, R.M., 1990. The properties of rice bran as a food stuff. Cereal Food World 35: 632-662.

Secundo, F. and Guerrieri, N., 2005. ATR-FT/IR study on the interactions between gliadins and dextrin and their effects on protein secondary structure. Journal of Agricultural and Food Chemistry 53: 1757-1764.

Shoji, Y., Mita, T., Isemaru, M., Mega, T., Hase, S., Isemura, S. and Aoyagi, Y., 2001. A Fibronectin-binding protein from rice bran wit cell adhesion activity for animal tumor cells. Bioscience Biotechnology and Biochemistry 65: 1181-1186.

Tang, S., Hettiarachchy, N.S., Horax, R. and Eswaranandam, S., 2003. Physicochemical properties and functionality of rice bran protein hydrolyzate prepared from heat-stabilized defatted rice bran with the aid of enzymes. Journal of Food Science 68: 152-157. 
